\title{
Application of a gradient UHPLC method for determination of chemical and physiological stability of pyrrole-containing ester derivative
}

\author{
S. Vladimirova ${ }^{1}$, M. Georgieva ${ }^{2 *}$ and Al. Zlatkov ${ }^{2}$ \\ ${ }^{1}$ Department of Organic synthesis and fuels, University of Chemical Technology and Metallurgy, Sofia, Bulgaria \\ ${ }^{2}$ Department of Pharmaceutical chemistry, Faculty of Pharmacy, Medical University-Sofia, Sofia, Bulgaria
}

\begin{abstract}
This paper proposes a simple and selective UHPLC method for determination of degradation products of a model pyrrole based compound, containing susceptible to hydrolysis ester group. The chromatographic separation was achieved on BDSHYPERSILC18 $(150 \mathrm{~mm} \times 4.6 \mathrm{~mm}, 3.5 \mu \mathrm{m})$ column thermostated at $30^{\circ} \mathrm{C}$ under

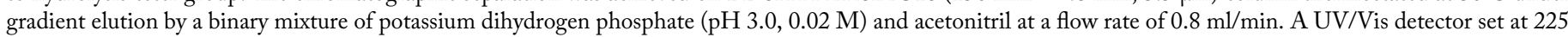
$\mathrm{nm}$ was used for detection. The stability testing was carried out under acidic ( $\mathrm{pH} 1.2$ and $\mathrm{pH} 4.5$ ), normal (pH 6.8) and alkaline (pH 13) conditions at temperature of $37^{\circ} \mathrm{C}$. At moderate and low alkali $\mathrm{pH}$ and temperatures the compound was stable. In acidic media the model compound is transformed into its degradation product. The developed method is validated with respect to suitability, linearity, precision, accuracy and selectivity and can be implemented for stability testing of pyrrolecontaining ester derivatives.
\end{abstract}

\section{Introduction}

The stability of a compound synthesized as a potential medicinal agent is related to the pharmacokinetic behavior in the body and to the conditions for the formulation, storage, occurrence of toxic effects associated with degradation products and so on. Most of compounds are fairly stable in the neutral $\mathrm{pH}$ value found in the intestine but can be unstable at the $\mathrm{pH}$ value found in the stomach [1]. Thus in the development of new drugs early information of stability becomes essential for subsequent processes of optimization and selection of leading active structures and can prevent unnecessary costs on developing products that subsequently prove to be unstable.

In this regard, the synthesis and determination of stability at different physiological conditions of the new compounds with potential anti-inflammatory activity is of particular importance. Forced degradation testing performed according to the regulatory guidance suggests, that potential degradation products are formed through elevated temperatures, by applying acidic, basic, and oxidative conditions, and through photolysis [2]. Several high-performance liquid chromatography (HPLC) methods are reported in the literature for the identification and quantification of degradation of different pharmaceutical substances in various media [3-8].

The aim of this study is to establish and apply a ultra-high performance liquid chromatography (UHPLC) method for identification of hydrolytic degradation products from newly synthesized pyrrolyl-ester derivative.

\section{Materials and methods}

\section{Chemicals and reagents}

All commercial chemicals used in this study as starting materials and reagents were purchased from "Merck" (Darmstadt, Germany). The melting point was determined with a capillary digital melting point apparatus IA 9200 Electrothermal AZ9003MK4, South end-onSea, UK. The IR spectra were registered on Specord IR-71, Carl Zeiss, Jena, Germany $(\mathrm{KBr})$. The ${ }^{1} \mathrm{H}$ NMR spectra $\left(250 \mathrm{MHz}, 20^{\circ} \mathrm{C}\right)$ was registered on a BrukerSpectrospin WM250 spectrometer (Faenlanden, Switzerland), using TMS as internal standard. TLC characteristic of the product was measured on aluminum sheets of silica gel $60 \mathrm{~F}_{254}$, Merck 1.05554 at ambient temperature using a mobile phase chloroformethanol.

The necessary products for preparation of the mobile phase and used buffers are of analytical grade, whereas potassium dihydrogen phosphate dihydrate (Sigma-Aldrich, Steinheim, Germany), orthophosphoric acid (Merck, Darmstadt, Germany) and acetonitrile (ACN) gradient grade (Sigma-Aldrich, Steinheim, Germany) were used.

\section{Instrumentation and chromatographic conditions}

The chromatographic analysis was performed on a system UHPLCDionexUltiMate 3000 with UV/Vis detector (Shimadzu, Kyoto, Japan). A BDSHYPERSILC18 (150 mm x $4.6 \mathrm{~mm}, 3.5 \mu \mathrm{m})$ column was employed for separation and isolation of degradation product using acetonitrile $\left(\mathrm{CH}_{3} \mathrm{CN}\right) /$ phosphate buffer $(\mathrm{pH} 3.0,0.02 \mathrm{M}) 40 / 60(\mathrm{v} / \mathrm{v})$ as

Correspondence to: Maya Boyanova Georgieva, PhD, Department of Pharmaceutical chemistry, Faculty of Pharmacy, Medical University-Sofia, 1000, Sofia, Bulgaria, Tel: +35929236530; Fax:+35929236505; E-mail: georgm@mail.bg

Key words: chemical stability, hydrolysis, physiological stability, pyrrole

Received: November 01, 2016; Accepted: November 14, 2016; Published: November 17, 2016 
mobile phase $\mathrm{A}$ and $\mathrm{CH}_{3} \mathrm{CN}$ as mobile phase $\mathrm{B}$ with a gradient elution with flow rate of $0.8 \mathrm{ml} / \mathrm{min}$ and detection at $225 \mathrm{~nm}$ (Table 1). The column oven was conditioned at $30^{\circ} \mathrm{C}$. The injection volume was $20 \mu \mathrm{l}$ with analysis time of 25 minutes.

\section{Preparation of buffer component of mobile phase}

$2.70 \mathrm{~g}$ of potassium dihydrogen phosphate dihydrate was dissolved in $1 \mathrm{Ll}$ of ultrapure water. An orthophosphoric acid solution (6\%) was used to adjust the $\mathrm{pH}$ to $3.0( \pm 0.05)$. The mobile phase buffer was filtered through a membrane filter $(0.20 \mu \mathrm{m})$ using a Millipore glass filter holder. The mobile phase buffer was used immediately after preparation or stored in the refrigerator in closed borosilicate glass bottles for a maximum of 24 hours

\section{Mobile phase composition:}

Mobile phase A - $\mathrm{CH}_{3} \mathrm{CN} /$ phosphate buffer $\mathrm{pH} 3.0=40 / 60(\mathrm{v} / \mathrm{v})$.

Mobile phase $\mathrm{B}-\mathrm{CH}_{3} \mathrm{CN}$.

The aim of this study is to identify, validate and apply a gradient UHPLC method for determination of chemical and physiological stability of pyrrole-containing ester derivative.

\section{Results and discussion}

\section{Selection of a model compound}

The fully substituted pyrrole, as well as the connected with it methyl groups are stable at moderate temperatures and in wide range of $\mathrm{pH}$ values. In previous studies, we have synthesized many pyrrolebased compounds bearing a variety of functional groups, like ethoxycarbonyle, acetyl, carboxamide etc on $3^{\text {rd }}$ position in the heterocycle [9]. Thus we considered that the stability of the obtained structures will be determined by the stability of the identified as potential "vulnerable" groups susceptible to hydrolysis ester and to lower extend amide groups positioned on $3^{\text {rd }}$ place in the pyrrole cycle (Figure 1)[10].

In order to confirm this $\mathbf{1} \mathbf{A}$ was chosen as a model compound [11]. The structure of the analyzed molecule is presented on Figure 1.

\section{Synthesis of the hydrolysis product}

The hydrolysis of the ester substituent at $3^{\text {rd }}$ position into the corresponding carboxylic group was defined as the most probable

Table 1. Linear gradient program.

\begin{tabular}{|c|c|c|c|}
\hline Time $[\mathbf{m i n}]$ & Flow $[\mathbf{m l} / \mathbf{m i n}]$ & $\mathbf{\%} \mathbf{A}$ & $\mathbf{\% ~ B ~}$ \\
\hline 0.0 & 0.8 & 100 & 0 \\
\hline 5.0 & 0.8 & 100 & 0 \\
\hline 12.5 & 0.8 & 25 & 75 \\
\hline 20.0 & 0.8 & 25 & 75 \\
\hline 22.0 & 0.8 & 100 & 0 \\
\hline 25.0 & 0.8 & 100 & 0 \\
\hline
\end{tabular}<smiles>CCOC(=O)c1cc(-c2ccc(Cl)cc2)n(C(C)C(=O)O)c1C</smiles>

Figure 1: Chemical structure of the chosen model compound 1A. chemical transition under the evaluated conditions.

Thus as referent compound the corresponding di-carboxylic acid $\mathbf{2 A}$, where the ester group on $3^{\text {rd }}$ position is replaced with the carboxylic group was synthesized. The structures of the evaluated ester and its hydrolitical acid product are presented on Figure 2.

The reference product was obtained by alkaline hydrolysis according to the described synthetic procedure where 0.10 moles of 1-(1-Carboxyethyl)-5-(4-chloro-phenyl)-2-methyl-1H-pyrrole-3-carboxylic acid ethyl ester (1A) were dissolved in ethanol $(140 \mathrm{ml})$ and $25 \% \mathrm{NaOH}(70$ $\mathrm{ml}$ ) were added. The reaction was run at the water bath boiling point and the process was monitored by thin layer chromatography (TLC). After reaction completion ( 2 hours), the mixture was cooled down and $20 \% \mathrm{HCl}$ were added, until $\mathrm{pH}$ 2.0. The separated precipitate was filtered off, washed with water to $\mathrm{pH} 7.0$, dried and recrystallized from warm ethanol. The structure of the obtained product was elucidated by the corresponding IR and ${ }^{1} \mathrm{H}-\mathrm{NMR}$ spectral data. The yield was calculated for the chromatographically pure product (Scheme 1) [12].

1-(1-Carboxy-ethyl)-5-(4-chloro-phenyl)-2-methyl-1H-pyrrole3-carboxylicacid(2A): White solid, Yield 70\%, mp 194-196 ${ }^{\circ} \mathrm{C}, R_{f} 0.63$ $\left(10: 0.3 / \mathrm{CHCl}_{3}: \mathrm{C}_{2} \mathrm{H}_{5} \mathrm{OH}\right)$. IR spectrum $(\mathrm{KBr}), \quad v, \mathrm{~cm}^{-1}$ : 3600-2400 $(\mathrm{COOH}), 3300(\mathrm{O}-\mathrm{H}), 1720,1695(\mathrm{C}=\mathrm{O}), 830\left(p-\mathrm{C}_{6} \mathrm{H}_{4}\right) ;{ }^{1} \mathrm{H}$ NMR spectrum $\left(250 \mathrm{MHz}, \mathrm{DMSO}-d_{6}\right), \delta, \operatorname{ppm}(J, \mathrm{~Hz}): 1.55(\mathrm{~d}, 3 \mathrm{H}, J=7.1$, $\left.\mathrm{CHCH}_{3}\right) ; 2.50\left(\mathrm{~s}, 3 \mathrm{H}, \mathrm{CH}_{3}-2\right), 4.60-4.80(\mathrm{~m}, 1 \mathrm{H}, \mathrm{CHCOOH}), 6.40(\mathrm{~s}, 1 \mathrm{H}$, $\mathrm{H}-4), 7.15-7.25\left(\mathrm{~m}, 4 \mathrm{H}, \mathrm{C}_{6} \mathrm{H}_{4}\right), 11.90 \mathrm{ppm}-\mathrm{bs}, 2 \mathrm{H}, \mathrm{OH}(\mathrm{OH}$ protons were $\mathrm{D}_{2} \mathrm{O}$ exchangeable).

\section{Validation of the gradient UHPLC analytical procedure}

The method was validated according to ICH Q2 (R1) guidelines [13]. The system suitability (i.e., repeatability of retention times and areas, number of theoretical plates, and resolution), precision, linearity, accuracy and selectivity were evaluated during method validation (Table 2). The parameters accuracy, precision, and selectivity were evaluated for the two analyzed products.

Precision: Six sample solutions were prepared from each of the evaluated substances. Each sample was injected three times. The final results are reported as relative standard deviations (RSD) of the $\mathbf{1 A}$ and $2 \mathrm{~A}$ ratios of the peak areas.

Linearity: A 5 points calibration curve was create, covereing the<smiles>CCOC(=O)c1cc(-c2ccc(Cl)cc2)n(C(C)C(=O)O)c1C</smiles><smiles>Cc1c(C(=O)O)cc(-c2ccc(Cl)cc2)n1C(C)C(=O)O</smiles>

Scheme 1: A synthetic access to the targeted product 2A.<smiles>CCOC(=O)c1cc(-c2ccc(Cl)cc2)n(C(C)C(=O)O)c1C</smiles><smiles>Cc1c(C(=O)O)cc(-c2ccc(Cl)cc2)n1C(C)C(=O)O</smiles>

Figure 2: Structure of the evaluated compound (1A) and its probable hydrolytic product (2A). 
concentration range of $\mathbf{1 A}$ from $0.02 \mathrm{mg} / \mathrm{ml}$ to $0.1 \mathrm{mg} / \mathrm{ml}$. Linear regression was used to process the calibration data. The correlation coefficients of linearity was 0.9997 for $\mathbf{1 A}$, which indicate good correlation between the peak areas and the range of concentrations studied.

Accuracy: The solutions for injection were prepared using a placebo and stock solution of the tested structures. Six solutions were prepared from each of the two compounds. Each solution was injected onto the column three times. Accuracy is reported as a parameter recovery with relative standard deviations.

Selectivity: The selectivity was determined by comparing the chromatograms of sample solutions, standard solution, and blank solutions. Figure 3 shows that the two tested compounds are all completely separated from each other. No interference was observed.

\section{Determination of the stability at different $\mathrm{pH}$}

Chemical stability: By definition the chemical stability is determined as the tendency of a substance to sustain to changes or decay, caused by internal reaction or affected by air, humidity, heat, light, pressure etc. The compound presented in this paper has been stored for 6 months period at room temperature with access to air and light. The physical and chemical properties of the compound were determined to be unchanged under these conditions. The tested compound may be considered chemically stable.

Physiological stability: An important factor influencing the performance of the molecules in the organism is their hydrolytic stability at physiological conditions, such as: body temperature of $37^{\circ} \mathrm{C}$ and physiological pH of 1.2 (in stomach), 4.5 (in urine) and 6.8 (in blood plasma) [14].

\section{Hydrolytic stability study at close to physiological conditions}

Due to the poor solubility of the analyzed structure in water, for the evaluation of the stability anacetonitrile:buffer solutions were prepared at the necessary relevant ratio, in order to obtain the desired $\mathrm{pH}$ values, close to physiological. A $20 \mathrm{mg}$ sample of the model compound was weighed and dissolved in the corresponding mixture of acetonitrile: buffer 1.2, 4.5, 6.8 and 13, respectively. The obtained solutions were termostated and stirred in a micro reactor at $37^{\circ} \mathrm{C}$ for a total time of $1440 \mathrm{~min}$. An aliquot samples of $0.5 \mathrm{ml}$ of the analyzed solutions were drawn at definite time intervals $(15,30,60,120,240,480$ and $1440 \mathrm{~min})$ and diluted up to $1.5 \mathrm{ml}$ with the corresponding mobile phase in a way that the concentration is in the range of $0.1 \mathrm{mg} / \mathrm{ml}$ and a $20 \mu \mathrm{l}$ sample was injected. The corresponding chromatograms were obtained.

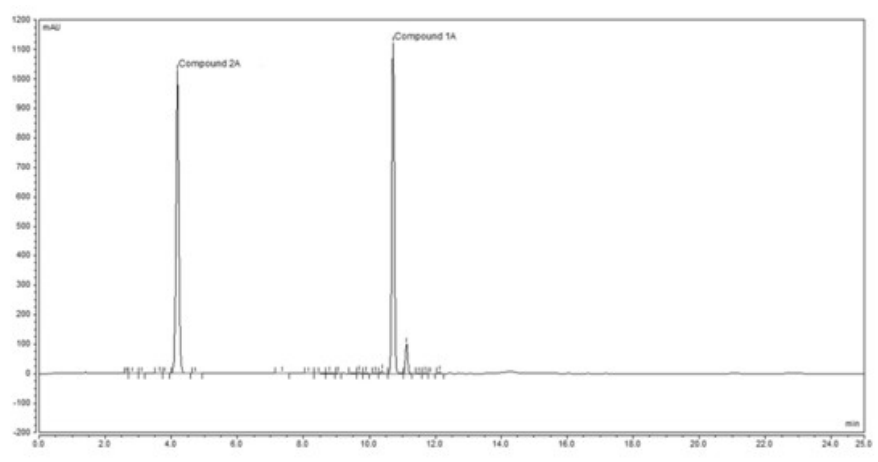

Figure 3: Retention times of the hydrolytic product $2 \mathrm{~A}$ (4.2 min.) and the evaluated compound 1A (11.0 min.), respectively.

\section{Stability determination of compound $1 \mathrm{~A}$ at $\mathrm{pH} 1.2$ (stomach) and temperature of $37^{\circ} \mathrm{C}$}

Preparation of buffer $\mathbf{p H}$ 1.2: A mixture of $0.2 \mathrm{~mol} / \mathrm{l} \mathrm{NaCl}$ (solution A) and $0.2 \mathrm{~mol} / \mathrm{l} \mathrm{HCl}$ (solution B) is prepared, where $25 \mathrm{ml}$ of solution A are mixed with $42.5 \mathrm{ml}$ of solution $\mathrm{B}$. The obtained mixture is diluted up to $100 \mathrm{ml}$ with distilled water.

A $20 \mathrm{mg}$ sample of the model compound was weighed and dissolved in the corresponding mixture of acetonitrile: buffer $\mathrm{pH} 1.2$. The obtained solutions were stirred in a micro reactor at $37^{\circ} \mathrm{C}$ for a total time of $1440 \mathrm{~min}$. An aliquot $20 \mu \mathrm{l}$ samples were drawn at the defined above time intervals and injected into the UHPLC system. The obtained chromatogram is presented on Figure 4.

An appearance of a small peak at the retention time corresponding to $\mathbf{2 A}$ (4.0 min.) is observed. In addition a kinetic study of the established degradation was also performed.

Kinetic evaluation of degradation of compound $1 \mathrm{~A}$ at $\mathrm{pH} \mathbf{1 . 2}$ (stomach) and temperature of $37^{\circ} \mathrm{C}$

The corresponding time dependence curve for degree of degradation of compound $\mathbf{1 A}$ at $\mathrm{pH}=1.2$ and temperature of $37^{\circ} \mathrm{C}$ was drawn and presented on Figure 5.

The obtained results reveal about two times accumulation of the hydrolytic product $\mathbf{2 A}$ for a $24 \mathrm{~h}$ period. A second degree polynomial dependency is observed with $\mathrm{R}^{2}$ of 0.995 .

\section{Stability determination of compound $1 \mathrm{~A}$ at $\mathrm{pH} 4.5$ (urine) and temperature of $37^{\circ} \mathrm{C}$}

Preparation of buffer $\mathbf{p H}$ 4.5: A $2 \mathrm{~mol} / \mathrm{C}_{3} \mathrm{COOH}$ solution (solution A) is prepared. $0.299 \mathrm{~g}$ of $\mathrm{CH}_{3} \mathrm{COONa}$ and $1.4 \mathrm{ml}$ solution A are mixed and diluted to $100 \mathrm{ml}$ with distilled water.

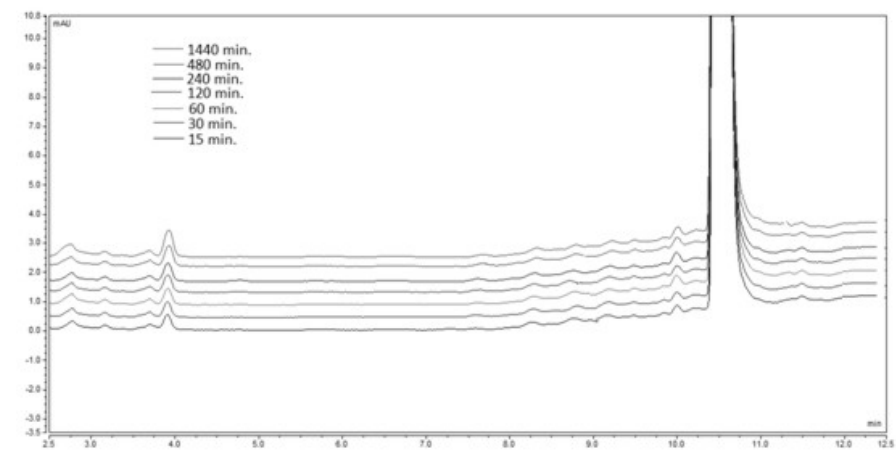

Figure 4: Chromatogram of the analyzed product $1 \mathrm{~A}$ at $\mathrm{pH} 1.2$ and temperature of $37^{\circ} \mathrm{C}$.

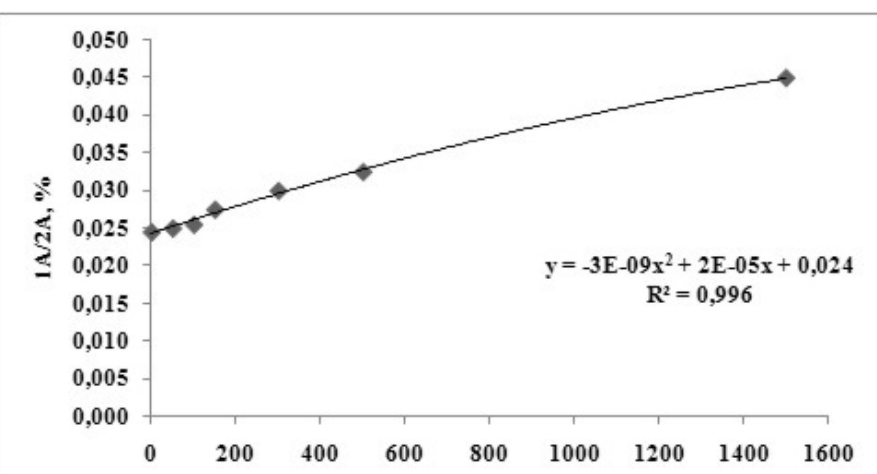

Figure 5: Time dependent degradation of $1 \mathrm{~A}$ at $\mathrm{pH} 1.2$ and temperature of $37^{\circ} \mathrm{C}$. 
A $20 \mathrm{mg}$ sample of the model compound was weighed and dissolved in the corresponding mixture of acetonitrile: buffer $\mathrm{pH}$ 4.5. The obtained solutions were stirred in a micro reactor at $37^{\circ} \mathrm{C}$ for a total time of $1440 \mathrm{~min}$. An aliquot $20 \mu \mathrm{l}$ samples were drawn at the defined above time intervals and injected into the UHPLC system. The obtained chromatogram is presented on Figure 6.

No new peak, corresponding to the retention time of the degradation product $\mathbf{2 A}$, is formed. The performed kinetic evaluation presented on Figure 7 demonstrates that for the tested period of 1440 min. ( $24 \mathrm{~h})$ no chemical transformation of the analysed pyrrole ester $\mathbf{1 A}$ is observed under the evaluated conditions.

Stability determination of compound $1 \mathrm{~A}$ at $\mathrm{pH} 6.8$ (blood plasma) and temperature of $37^{\circ} \mathrm{C}$

Preparation of buffer $\mathbf{p H}$ 6.8: A mixture of $0.2 \mathrm{~mol} / \mathrm{l} \mathrm{KH}_{2} \mathrm{PO}_{4}$ (solution A) and $0.2 \mathrm{~mol} / \mathrm{l} \mathrm{NaOH}$ (solution B) is prepared, where 25 $\mathrm{ml}$ of solution A are mixed with $11.2 \mathrm{ml}$ of solution $\mathrm{B}$. The obtained mixture is diluted to $100 \mathrm{ml}$ with distilled water.

A $20 \mathrm{mg}$ sample of the model compound was weighed and dissolved in the corresponding mixture of acetonitrile: buffer $\mathrm{pH} 6.8$. The obtained solutions were stirred in a micro reactor at $37^{\circ} \mathrm{C}$ for a total time of $1440 \mathrm{~min}$. An aliquot $20 \mu \mathrm{l}$ samples were drawn at the defined above time intervals and injected into the UHPLC system. The obtained chromatogram is presented on Figure 8.

As seen from the presented chromatogram no new peak, corresponding to the retention time of the degradation product $\mathbf{2 A}$, is formed.

The performed kinetic evaluation presented on figure 9

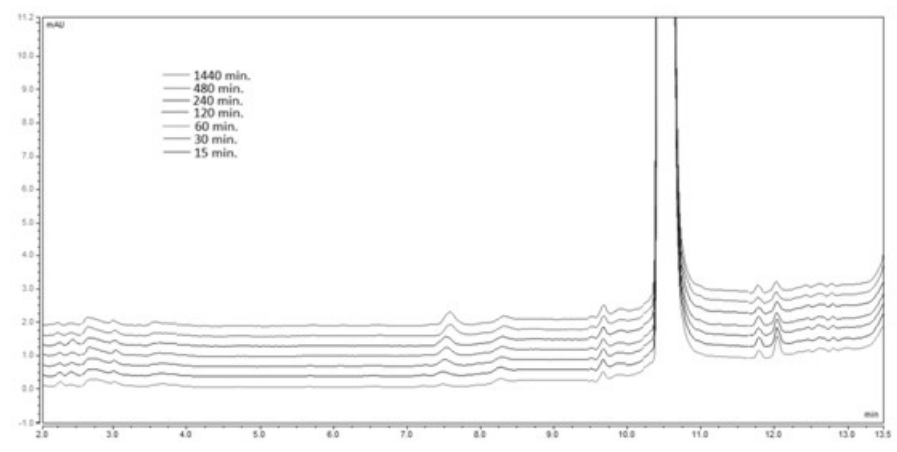

Figure 6: Chromatogram of the analyzed sample $1 \mathrm{~A}$ at $\mathrm{pH} 4.5$ and temperature of $37^{\circ} \mathrm{C}$.

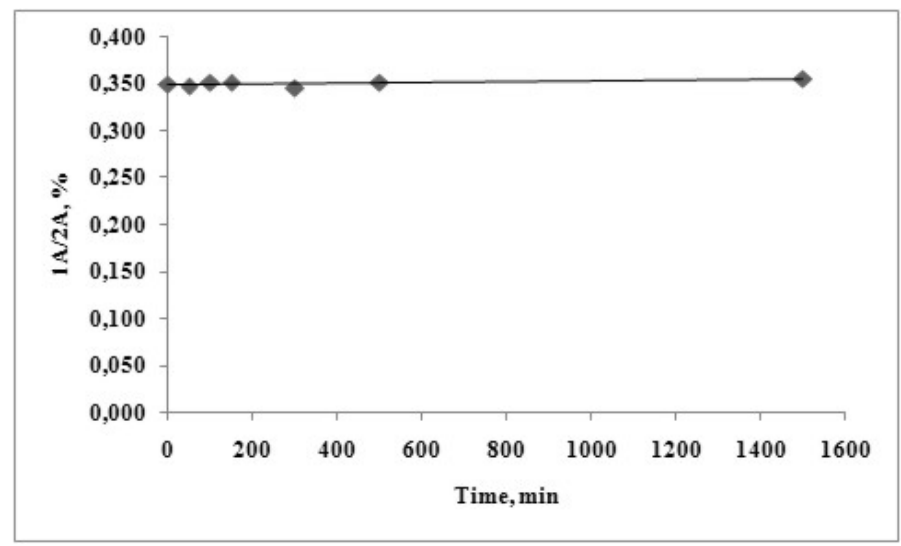

Figure 7: Time dependent degradation of $1 \mathrm{~A}$ at $\mathrm{pH} 4.5$ and temperature of $37^{\circ} \mathrm{C}$.

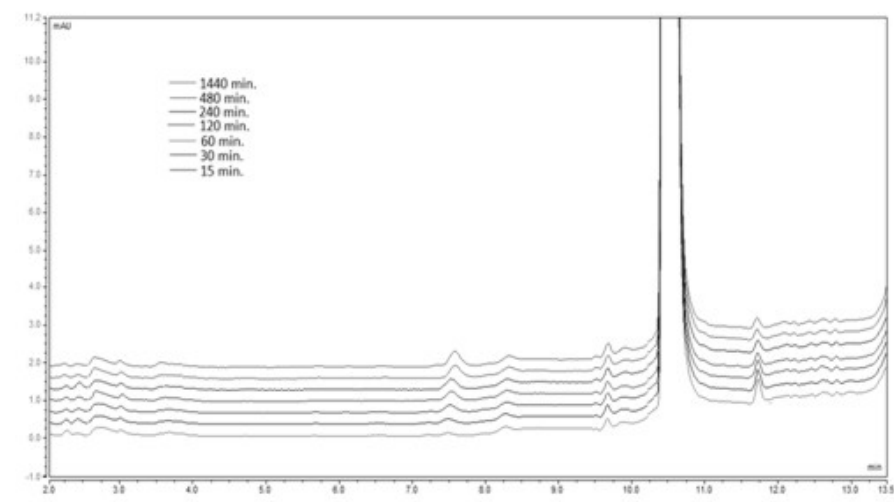

Figure 8: Chromatogram of the analyzed sample $1 \mathrm{~A}$ at $\mathrm{pH} 6.8$ and temperature of $37^{\circ} \mathrm{C}$

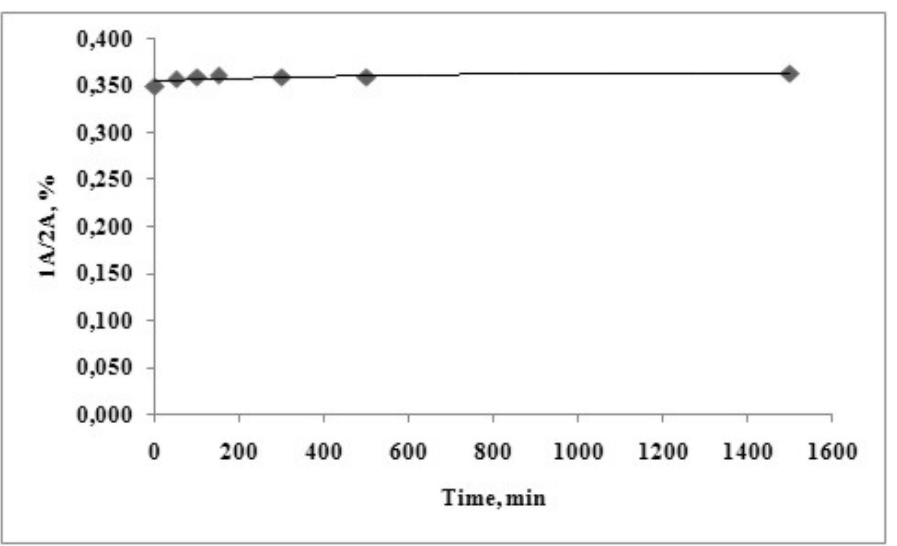

Figure 9: Time dependent degradation of $1 \mathrm{~A}$ at $\mathrm{pH} 6.8$ and temperature of $37^{\circ} \mathrm{C}$.

demonstrates that for the tested period of $1440 \mathrm{~min}$. (24 h) no chemical transformation of the analysed pyrrole ester $\mathbf{1 A}$ is observed under the evaluated conditions.

\section{Stability determination of compound $1 \mathrm{~A}$ at $\mathrm{pH} 13$ and temperature of $37^{\circ} \mathrm{C}$}

Preparation of buffer $\mathbf{p H}$ 13: A standard buffer with $\mathrm{pH} 13(\mathrm{KCl} /$ $\mathrm{NaOH}$ ) was used for the current study.

A $20 \mathrm{mg}$ sample of the model compound was weighed and dissolved in the corresponding mixture of acetonitrile: buffer $\mathrm{pH} 13$. The obtained solutions were stirred in a micro reactor at $37^{\circ} \mathrm{C}$ for a total time of $1440 \mathrm{~min}$. An aliquot $20 \mu \mathrm{l}$ samples were drawn at the defined above time intervals and injected into the UHPLC system. The obtained chromatogram is presented on Figure 10.

As seen from the presented chromatogram well defined new peaks, appearing at the retention time of the degradation product $\mathbf{2 A}$, are formed, starting from the $15^{\text {th }}$ min of incubation.

\section{Kinetic evaluation of degradation of compound $1 \mathrm{~A}$ at $\mathrm{pH} 13$} and temperature of $37^{\circ} \mathrm{C}$

The corresponding time dependence curve for degree of degradation of compound $\mathbf{1} \mathbf{A}$ at $\mathrm{pH}=13$ and temperature of $37^{\circ} \mathrm{C}$ was drawn and presented on Figure 11.

From the obtained graphical dependency a fast hydrolysis is revealed. A second degree polynomial dependency is observed with $\mathrm{R}^{2}$ of 0.9996 . Almost 80 -fold increase in the amount of $\mathbf{2 A}$ is registered for a $24 \mathrm{~h}$ period. 


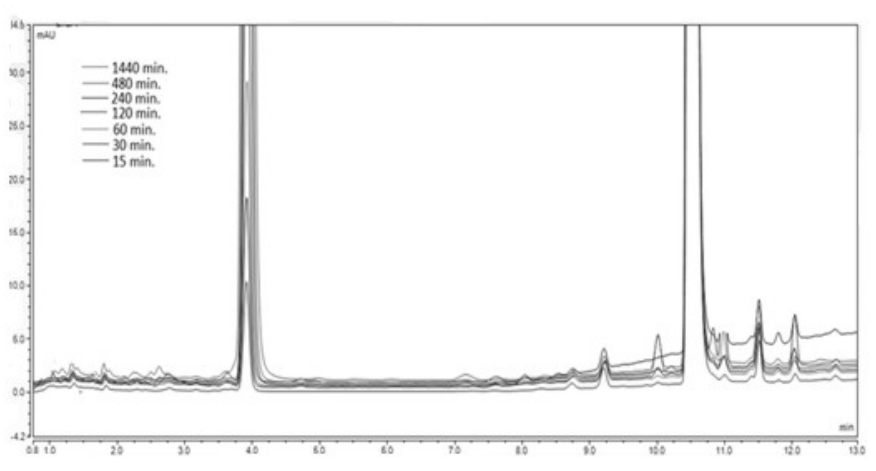

Figure 10: Chromatogram of the analyzed sample $1 \mathrm{~A}$ at $\mathrm{pH} 13$ and temperature of $37^{\circ} \mathrm{C}$.

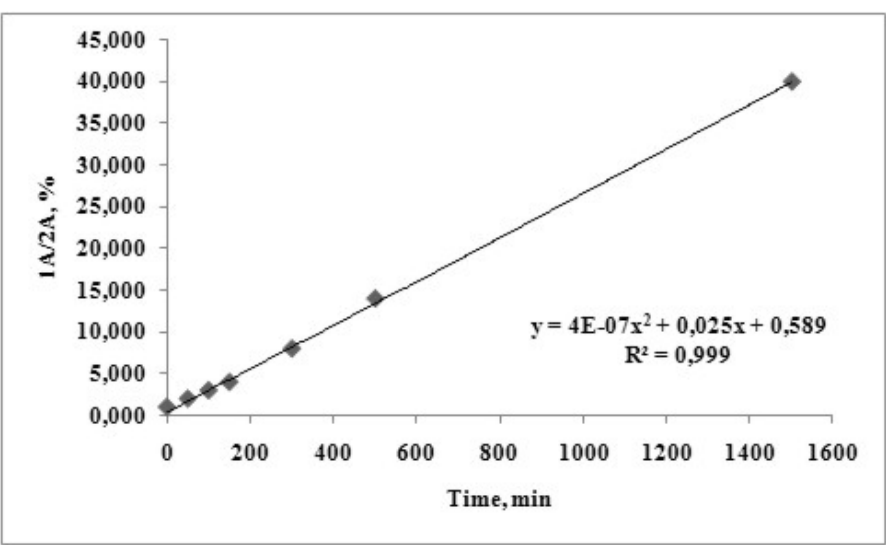

Figure 11: Time dependent degradation of $1 \mathrm{~A}$ at $\mathrm{pH} 13$ and temperature of $37^{\circ} \mathrm{C}$. Table 2. Validation parameters for compounds $1 \mathrm{~A}$ and $2 \mathrm{~A}$.

\begin{tabular}{|l|c|c|c|}
\hline & 1A & 2A & Criterion \\
\hline Repeatability $\mathrm{t}_{\mathrm{R}}$ (\% RSD) & 0.00 & 0.00 & $X<1 \%$ \\
\hline Number of Theoretical plates & 50000 & 10000 & - \\
\hline Resolution* & 7.3 & 7.3 & $\mathrm{R}_{\mathrm{ij}}>1.5$ \\
\hline Precision (\% RSD) & 1.0 & 1.0 & $X<5 \%$ \\
\hline $\begin{array}{l}\text { Linearity (correlation } \\
\text { coefficient) }\end{array}$ & 0.9997 & 0.9997 & $\mathrm{R}>0.9990$ \\
\hline Accuracy (\%) & 100.1 & 99.97 & $X=100 \pm 5 \%$ \\
\hline Selectivity & No interference & No interference & No interference \\
\hline
\end{tabular}

" Six injections.

\# Two samples, three injections of each sample.

${ }^{8}$ At 50, 100, 150, 200 and $250 \%$ concentration level.

$\%$ RSD: Relative standard deviation in \%

\section{Conclusion}

A gradient UHPLC method was used and validated for determination of chemical stability and stability under close to physiological conditions of a pyrrole-containing ester derivative. The proposed method was found to be accurate, precise, reproducible and specific. The results indicate that the tested compound is stable at moderate and low alkali $\mathrm{pH}$ and temperatures, but susceptible to hydrolysis in strong acidic ( $\mathrm{pH} 1.2)$ and strong alkali ( $\mathrm{pH} 13)$ media. As degradation product the corresponding di-carboxylic acid is obtained.

\section{References}

1. Zajac M, Sobczak A, Malinka W, Redzicka A (2010) The stability of N-[2-(4-ofluorophenylpiperazin-1-yl)ethyl]-2,5-dimethyl-1-phenylpyrrole-3,4-dicarboximide in aqueous-organic solutions. Acta Pol Pharm 67: 27-33. [Crossref]

2. International Council for Harmonisation, Guidance for industry Q1A(R2), 2003 Stability testing of new drug substances and products.

3. Svirskis D, Travas-Sejdic J, Garg S (2011) A Stability Indicating HPLC Method for the Determination of Electrochemically Controlled Release of Risperidone. J Chromatogr Sci 49: 780-785. [Crossref]

4. Chaudhari BG, Patel NM, Shah B (2007) Stability Indicating RP-HPLC Method for Simultaneous Determination of Atorvastatin and Amlodipine from Their Combination Drug Products. Chem Pharm Bull(Tokyo) 55: 241-246. [Crossref]

5. Gatti R, Gioia MG, Leoni A, Andreani A (2010) 2,5-Dimethyl-1H-pyrrole-3,4 dicarbaldehyde as a precolumn derivatization reagent for HPLC/UV detection of amino acids. J Pharm Biomed Anal 53: 207-211. [Crossref]

6. Hadad GM (2008) Validated stability-indicating HPLC method for the determination of dimethyl-4,4'-dimethoxy-5,6,5',6'-dimethylenedioxybiphenyl-2,2'-dicarboxylate (DDB) and its degradation products. Journal of Pharmaceutical and Biomedical Analysis 47: 695-703.

7. El-Gindy A (2005) High performance liquid chromatographic determination of oxeladin citrate and oxybutynin hydrochloride and their degradation products. Farmaco 60: 689699. [Crossref]

8. Wagieh NE, Hegazy MA, Abdelkawy M, Abdelaleem EA (2010) Quantitative determination of oxybutynin hydrochloride by spectrophotometry, chemometry and HPTLC in presence of its degradation product and additives in different pharmaceutical dosage forms. Talanta 80: 2007-2015. [Crossref]

9. Vladimirova S, Bijev A (2014) An access to new N-pyrrolylcarboxylic acids as potential COX-2 inhibitors via Paal-Knorr cyclization. Heterocyclic Communications 20: $111-115$.

10. Jordanov S, Dimitrov G, Mancheva I, Stoianova R (1994) Organic chemistry basics, Textbook, Sofia.

11. Minchev I, Vladimirova S, Vezenkov L, Bijev A, Moussis V, et al. (2007) Design, synthesis and biological evaluation of Antipicorna viral pyrrole-containing peptidomimetics. Protein \& Peptide Letters 14: 917-922.

12. Theodorou V, Skobridis K, Tzakos AG, Ragoussis V (2007) A simple method for the alkaline hydrolysis of esters. Tetrahedron Letters 48: 8230-8233.

13. International Council for Harmonisation, Expert Working Group, 2005. Validation of Analytical Procedures: TextandMethodology Q2(R1)

14. Kong F, Singh RP (2008) Disintegration of solid foods in human stomach. J Food Sci 73: R67-80. [Crossref]

Copyright: (C2016 Vladimirova S. This is an open-access article distributed under the terms of the Creative Commons Attribution License, which permits unrestricted use, distribution, and reproduction in any medium, provided the original author and source are credited. 